\title{
EVALUATION OF SUBSOIL COMPACTION OF PLASTIC SOILS ${ }^{1}$
}

\author{
Kinga Śnieg, Dariusz Błażejczak \\ Department of Construction and Usage of Technical Devices, \\ West Pomeranian University of Technology in Szczecin
}

"Corresponding author: e-mail: dariusz.blazejczak@zut.edu.pl

\begin{tabular}{|c|c|}
\hline ARTICLE INFO & ABSTRACT \\
\hline $\begin{array}{l}\text { Article history: } \\
\text { Received: October } 2016 \\
\text { Received in the revised form: } \\
\text { October } 2016 \\
\text { Accepted: November } 2016\end{array}$ & \multirow{2}{*}{$\begin{array}{l}\text { The objective of the research was to evaluate soil compaction with } \\
\text { selected indexes and to determine the relation between them including } \\
\text { results obtained with Proctor's method. Measurements of penetration } \\
\text { resistance and shear vane, dry density of soil particles }\left(\rho_{\mathrm{d}}\right) \text { and their } \\
\text { moisture were made in layers in the following depths: } 25-30,35-40 \text {, } \\
45-50 \text { and } 55-60 \mathrm{~cm} \text {. Moreover, the maximum volumetric density of } \\
\text { soil particles, particles size distribution, content of calcium carbonate } \\
\text { and humus, density of solid particles, reaction, plastic and liquid limit } \\
\left.\text { were determined with Proctor's method ( } \rho_{\mathrm{ds}}\right) \text {. Also, packing density } \\
\text { and natural density were measured. It was found out that the investi- } \\
\text { gated soils may be generally included to excessively compacted and } \\
\text { susceptible to compaction to an average and small degree. It was } \\
\text { shown that soil may be recognized as excessively compacted when the } \\
\text { quotient } \rho_{\mathrm{d}} / \rho_{\mathrm{ds}} \text { exceeds the value of } 0.87 \text {. }\end{array}$} \\
\hline $\begin{array}{l}\text { Key words: } \\
\text { soil, } \\
\text { density, } \\
\text { evaluation, } \\
\text { dry density, } \\
\text { Proctor's method }\end{array}$ & \\
\hline
\end{tabular}

\section{Introduction}

Excessive soil density, which results from mechanization of works, is one of the most serious problems of modern agriculture (van den Akker et al., 2003). Heavy clays, clays, and sandy loams are soils, which are particularly susceptible to compaction (Krasowicz et al., 2011). Excessive compaction of subsoil is mainly dangerous because the effects of compaction of this layer are long-lasting and its eradication through deep scarification is energy consuming and often ineffective (Szeptycki, 2003). A rational approach to counteracting this phenomenon requires evaluation of the present soil density and identification of conditions in which it takes place.

Dry density of solid particles is popular in the density tests. Direct application of results of measurements of dry density of solid particles for evaluation of its compaction condition in the context of its influence on the plants growth conditions causes many problems (Błażejczak and Dawidowski, 2013). These difficulties cause that scientists try to apply relevant measures of soil compaction as an indicator of evaluation of plant growth conditions (Hakansson and Lipiec, 2000).

1 This publication was written as a part of the project financed from the means of the National Scientific Centre (Contract no. 7808/B/P01/2011/40) 
Research results obtained with Proctor's method in the form of the maximum density and optimal moisture are parameters which are commonly used in geo-technology, which on one hand constitute a reference point in the evaluation of the soil density condition and on the other hand characterize the conditions of the maximum susceptibility. In the past, Proctor's method was used for description of susceptibility to compaction of agricultural soils (Wagner et al., 1994; Aragon et al., 2000). According to Soanne et al., (1980/1981) the use of Proctor's method for evaluation of the density of agricultural soils may be recognized as reasonable. The maximum value of dry density $\left(\rho_{\mathrm{ds}}\right)$, obtained in the standard Proctor's method, is considered as the maximum value possible to be obtained for a given soil (Kumar et al., 2009). It results from the fact that in this method homogeneous soil mass is compacted. The mass is susceptible to compaction more than soil with a natural structure and compaction energy is higher than the energy of the wheel impact on soil even in case of vehicles with considerably big weight (Barzegar et al., 2000).

\section{Objective, scope and methods of research}

The objective of the research was to evaluate the soil compaction in its subsoil with the selected indicators and to determine the relation between them including the results obtained with Proctor's method.

Plastic soils, located within the following towns constituted the research object: Nowy Przylep (NP), Obojno $(\mathrm{Ob})$, Ostoja $(\mathrm{Os})$, Kurcewo $(\mathrm{Ku})$, Reńsko $(\mathrm{Re})$ and Skarbimierzyce $(S k)$. These soils possibly enable obtaining high crops and are threatened by excessive compaction as a result of intense use. Research was carried out in 2012-2016 in layers at the following depths: 25-30, 35-40, 45-50 and 55-60 cm, in periods when spring $(W)$ and winter $(J)$ cultivation treatments are performed.

Penetration resistance $\left(Z_{\mathrm{w}}\right)$ and shear vane were tested $\left(S_{\mathrm{c}}\right)$ and actual moisture $\left(w_{\mathrm{a}}\right)$ and dry density of solid particles were determined $\left(\rho_{\mathrm{d}}\right)$. A penetrometer (Eijkelkamp, Penetrologger), equipped with a cone with a vertical angle of $30^{\circ}$ and the area of its base of $1 \mathrm{~cm}^{2}$, at the feed speed of $2 \mathrm{~cm} \cdot \mathrm{s}^{-1}$ were applied. To measure $S_{\mathrm{c}}$, Geonor, Vane Tester H-60 equipped with the tip with dimensions of $16 \times 32 \mathrm{~mm}$, with the measurement scope from 0 to $260 \mathrm{kPa}$ was used. To measure $w_{\mathrm{a}}$ and $\rho_{\mathrm{d}}$ samples collected with the use of Kopecky's cylinders were used. When, during collection of samples, soil cracking was reported in cylinders as a result of moisture deficiency in a given layer, the field research was repeated in another period ( $W$ or $J$ ), along with measurements of $Z_{\mathrm{w}}$ and $S_{\mathrm{c}}$. Measurements were carried out in two iterations, in points distanced from each other by 2-3 m, except for handlands and technological roads.

Moreover, soil material in the form of loose mass was collected from layers and it was later used to determine the selected properties with the methods provided in brackets, i.e.: textural group (Bouyoucosa-Casagrande's after Prószyński's modification), density of solid particles (a pycnometer method), humus content (Tiurin's method), calcium carbonate content (Scheibler's method), soil reaction (an electrometric method), maximum density and optimal moisture (Proctor's method), plastic limit (a surface rolling method), liquid limit, (Casagrande's method). Testing the maximum density $\left(\rho_{\mathrm{ds}}\right)$ and optimal moisture $\left(w_{\mathrm{opt}}\right)$ of soils was carried out according to PN-88/B-04481, using a cylinder with the volume of $1000 \mathrm{~cm}^{3}$ and compacting energy of $0.59 \mathrm{~J}$ per $1 \mathrm{~cm}^{3}$ of soil. Values $\rho_{\mathrm{ds}}$ and $w_{\mathrm{opt}}$ were cal- 
Evaluation of subsoil...

culated in the spot (point), where polynomials describing a particular experiment assumed the maximum value (Błażejczak et al., 2013). With the use of polynomials also dry density of solid particles was forecasted $\left(\rho_{\mathrm{dm}}\right)$ calculated for the present moisture $\left(w_{\mathrm{a}}\right)$. However, the scope of use of the forecasting model $\rho_{\mathrm{dm}}$ differed from the scope of moisture values obtained during determination of $\rho_{\mathrm{ds}}$. The bottom limit corresponded to the minimum moisture measured in the field and the top of its maximum value obtained in the Proctor's method. The results of field research and soil properties allowed calculation of packing density $\left(P_{\mathrm{d}}\right)$ after Jones et al., $(2003)$ and natural dry density $\left(\rho_{\mathrm{n}}\right)$ acc. to Wojtasik (1995).

\section{Results and their analysis}

Table 1 presents results of determination of own properties of the investigated soils. It may be noted that the research material which came from soils which were compacted in the state of high moisture face permanent and strong deformation. Soils measurements were carried mainly on account of their textural group, humus and calcium carbonate content, which was most probably reflected in the range of plastic and liquid limits which were respectively $14.1-31.4 \%$ of moisture content and $15.4-73.0 \%$ of moisture content. Specific density and soil reaction were less varied and they were respectively within 2.39-2.67 $\mathrm{g} \cdot \mathrm{cm}^{-3}$ and $\mathrm{pH}$ 5.08-6.86.

Table 2 presents results of measurement of actual properties of the investigated soils (dry density of solid particles $-\rho_{\mathrm{d}}$, present moisture $-w_{\mathrm{a}}$, permission resistance $-Z_{\mathrm{w}}$, shear vane $-S_{\mathrm{c}}$ and results of natural density calculations $\rho_{\mathrm{n}}$ ). In soils of objects $N P$ and $O s$ (layer: 25-30 cm) and $S k$ (layer: $25-30$ and $35-40 \mathrm{~cm}$ ), due to annually reoccurring draught, which lasts several weeks there was no possibility to carry out measurements in the $W$ period. In the above mentioned cases measurements were carried out in various years for the $J$ period, and the obtained differences $\rho_{\mathrm{d}}$, except for object $O s$, did not exceed the value of $0.1 \mathrm{~g} \cdot \mathrm{cm}^{-3}$, namely the one which Komornicki and Zasoński (1965) claim to be a border one for the purposes of practical; interpretation of the difference of packing density. In the period $W$ often higher value $\rho_{\mathrm{d}}$ was reported at lower moisture. Measured higher values $\rho_{\mathrm{d}}$ for the period $W$ may be justified with shrinking of soil as a result of decrease in its moisture. According to Dobrzański and Zawadzki (1993) fluctuations of soil moisture may result in the changes of its volume to $32 \%$ in relation to the type of soil opening. Based on the results $Z_{\mathrm{w}}$ it may be assumed that conditions of plant growth were impeded in 17 cases because the average permission resistance exceeded the value of $2000 \mathrm{kPa}$ i.e. recognized as a border one for correct growth of roots (Gregorich and Carter, 1997). On the other hand high values of soil shear in rotational movement which were obtained $\left(S_{c}\right)$, that often exceeded $100 \mathrm{kPa}$, indicate that the investigated soils in the periods $W$ or $J$ had low susceptibility to compaction. It results from the fact that along with the increase of $S_{\mathrm{c}}$ values of precompaction stress of soil, which are the measure of soil susceptibility to compaction, grow (Błażejczak, 2010). Low susceptibility to compaction of the investigated soils may be justified with their present moisture, whose average value was $0.84 \%$ of the value $P_{\mathrm{L}}$. 
Kinga Śnieg, Dariusz Błażejczak

Table 1.

Average values of own properties of soils for the selected objects and measured layers

\begin{tabular}{|c|c|c|c|c|c|c|c|c|c|}
\hline \multirow[t]{2}{*}{$\stackrel{\mathscr{V}}{\mathrm{n}}$} & 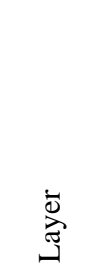 & 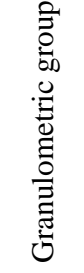 & 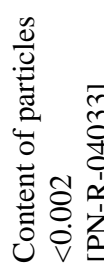 & 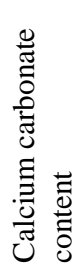 & 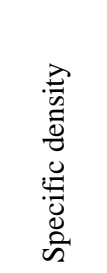 & 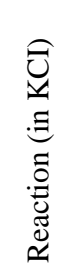 & 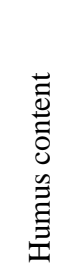 & 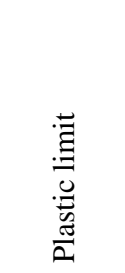 & 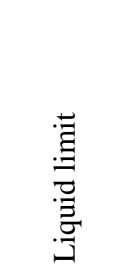 \\
\hline & $(\mathrm{cm})$ & & $(\%)$ & $(\%)$ & $\left(\mathrm{g} \cdot \mathrm{cm}^{-3}\right)$ & $(\mathrm{pH})$ & $(\%)$ & $(\% \mathrm{w} / \mathrm{w})$ & $(\% \mathrm{w} / \mathrm{w})$ \\
\hline \multirow{4}{*}{$N P$} & $25-30$ & SiL & 11.0 & 1.29 & 2.45 & 6.32 & 3.10 & 22.0 & 29.5 \\
\hline & $35-40$ & SiL & 11.0 & 2.53 & 2.46 & 6.34 & 2.02 & 21.3 & 31.2 \\
\hline & $45-50$ & SiL & 9.0 & 2.76 & 2.45 & 6.29 & 2.30 & 23.7 & 32.0 \\
\hline & 55-60 & $L$ & 15.0 & 0,68 & 2.47 & 6.21 & 1.09 & 20.3 & 31.3 \\
\hline \multirow{4}{*}{$O b$} & $25-30$ & $L$ & 27.0 & 0,10 & 2.45 & 6.86 & 4.17 & 25.9 & 44.2 \\
\hline & $35-40$ & $L$ & 27.0 & 0,07 & 2.49 & 6.84 & 3.77 & 28.0 & 47.9 \\
\hline & $45-50$ & $S i C L$ & 25.0 & - & 2.52 & 6.78 & 2.34 & 30.4 & 58.7 \\
\hline & $55-60$ & $\mathrm{SiC}$ & 17.0 & - & 2.40 & 6.52 & 1.70 & 31.4 & 73.0 \\
\hline \multirow{4}{*}{ Os } & $25-30$ & $S L$ & 9.0 & - & 2.52 & 5.08 & 1.03 & 14.1 & 17.0 \\
\hline & $35-40$ & $L$ & 15.0 & - & 2.66 & 5.13 & 0.61 & 18.4 & 27.6 \\
\hline & $45-50$ & $L$ & 21.0 & - & 2.67 & 5.23 & 0.69 & 19.8 & 30.3 \\
\hline & $55-60$ & $L$ & 20.0 & - & 2.55 & 5.63 & 0.57 & 18.0 & 28.8 \\
\hline \multirow{4}{*}{$R e$} & $25-30$ & SiL & 13.7 & 5.02 & 2.43 & 6.21 & 3.32 & 23.5 & 32.2 \\
\hline & $35-40$ & $L$ & 14.0 & 4.82 & 2.41 & 6.45 & 3.17 & 22.4 & 31.9 \\
\hline & $45-50$ & $L$ & 12.0 & 5.13 & 2.39 & 6.50 & 4.00 & 25.9 & 37.0 \\
\hline & 55-60 & $L$ & 14.0 & 0.52 & 2.44 & 6.43 & 2.91 & 22.0 & 31.8 \\
\hline \multirow{4}{*}{ Sk } & $25-30$ & $S C L$ & 22.0 & - & 2.50 & 6.23 & 1.78 & 21.8 & 39.2 \\
\hline & $35-40$ & $S C L$ & 25.0 & - & 2.64 & 6.25 & 1.05 & 17.9 & 27.5 \\
\hline & $45-50$ & $C L$ & 29.0 & - & 2.60 & 6.21 & 0.75 & 24.9 & 61.0 \\
\hline & $55-60$ & SiL & 20.0 & - & 2.53 & 6.22 & 0.68 & 27.4 & 52.5 \\
\hline \multirow{4}{*}{ Ku } & $25-30$ & $L$ & 11.5 & - & 2.66 & 6.82 & 0.54 & 14.2 & 15.4 \\
\hline & $35-40$ & $L$ & 20.4 & - & 2.63 & 6.36 & 0.42 & 19.0 & 39.2 \\
\hline & $45-50$ & $L$ & 23.3 & - & 2.60 & 6.16 & 0.31 & 20.8 & 38.3 \\
\hline & $55-60$ & $L$ & 24.3 & - & 2.59 & 6.69 & 0.34 & 26.7 & 46.2 \\
\hline
\end{tabular}
$\mathrm{SiC}$ - silty clay, SL - sandy loam, SCL - sandy clay loam, SL - clay loam, CL - clay loam

In order to carry out an assessment of the present compaction state, the obtained results (Table 2) were compared with threshold values $\rho_{\mathrm{d}}$ or $Z_{\mathrm{w}}$, suggested for the cultivated layer of various types of soils with specific parameters (Iancu, 2001). But the threshold value $Z_{w}$ was determined according to the suggested methodology adding or deducting a specific value of adjustment $(250 \mathrm{kPa})$ in relation to the difference of moisture measured and provided in tables. Moreover, content of silt and clay fraction $(<0.002 \mathrm{~mm})$ and plasticity index, namely a difference between the liquid and plastic limit were also taken into consideration (Table 1). Exceeding the threshold values $\rho_{\mathrm{d}}$ was reported in case of 29 
Evaluation of subsoil...

instances of measurements. But this case of exceeding $W$ or $J$ in a particular layer was reported in 9 cases. It may be noted that the number of cases when the threshold value was exceeded $\rho_{\mathrm{d}}$ is the lowest for objects $N P$ and $R e$ ( 2 for each), i.e. soils with granulation of silt loam and loam with the content of particles of $<0.002 \mathrm{~mm}$ which are within 9 to $15 \%$ (Table1). The highest number of instances where the threshold value was exceeded $\rho_{\mathrm{d}}$ was reported for the object $S k$, i.e. soils with granulation of sandy clay loam, silt loam with the content of particles of $<0.002 \mathrm{~mm}$ which are within 22 to $29 \%$. Contrary, the threshold value $Z_{\mathrm{w}}$, which proves excessive compaction of soil, was exceeded. It was reported only in 4 cases. It might have resulted from the fact that the suggested threshold values are related to the cultivation layer. On the other hand, this paper analyses the compaction state for the subsoil, where cultivation treatments are carried out from time to time (e.g. subsoiling) and properties of this layer diverge often from the arable layer. Also, the fact that distribution of the investigated soils to groups of soil forms suggested by Iancu (2001) may be treated approximately - differences in soil classification between the countries, is not without significance. Due to drawbacks of the above procedure for assessment of present permission resistance of subsoil the calculated values of natural volumetric density were used $\left(\rho_{\mathrm{n}}\right)$ acc. to Wojtasik (1995) based on which soil may be included to the category of natural density if the value $\rho_{\mathrm{d}}$ is within $\rho_{\mathrm{n}} \pm 0.05 \mathrm{~g} \cdot \mathrm{cm}^{-3}$. Soil may be also included to slightly, medium or strongly compacted if the difference $\rho_{\mathrm{d}}$ and $\rho_{\mathrm{n}}$ has a positive value and is respectively within: $\left(0.05-0.15>,\left(0.15-0.25>\right.\right.$ and $>0.25 \mathrm{~g}^{\circ} \mathrm{cm}^{-3}$. In a reverse situation, when the difference $\rho_{\mathrm{d}}$ and $\rho_{\mathrm{n}}$ has a negative value, soil may be included to slightly, medium or considerably scarified. The investigated objects (Table 2) were included to soils from slightly to strongly compacted in 25 cases. But, similarity to Iancu's procedure (2001) was obtained in 20 cases. Thus, it may be assumed that both procedures of assessment of soil compaction are comparable.

Table 2.

Average values of dry density of solid particles $\left(\rho_{d}\right)$, present moisture $\left(w_{a}\right)$, penetration resistance $\left(Z_{w}\right)$, shear resistance $\left(S_{c}\right)$ of soils of investigated objects in layers for spring $(W)$ and fall $(\mathrm{J})$ periods of field measurements and assessment of soil density assessment acc. to Iancu (2001) and Wojtasik (1995)

\begin{tabular}{|c|c|c|c|c|c|c|c|c|}
\hline $\begin{array}{c}\text { Facility } \\
\text { Layer }\end{array}$ & & $\begin{array}{l}\text { Period } \\
\text { of } \\
\text { measure } \\
\text { ments }\end{array}$ & $\rho_{\mathrm{d}}$ & $w_{\mathrm{a}}$ & $Z_{\mathrm{w}}$ & $S_{\mathrm{c}}$ & \multirow[t]{2}{*}{$\begin{array}{c}\text { Assessment of } \\
\text { density acc. to } \\
\text { Iancu (2001) } \\
\text { based on } \rho_{\mathrm{d}} / Z_{\mathrm{w}}\end{array}$} & \multirow{2}{*}{$\begin{array}{c}\text { Assessment } \\
\text { of density } \\
\text { acc. to } \\
\text { Wojtasik } \\
\text { (1995) }\end{array}$} \\
\hline & $(\mathrm{cm})$ & & $\left(\mathrm{g} \cdot \mathrm{cm}^{-3}\right)$ & $(\% \mathrm{w} / \mathrm{w})$ & $(\mathrm{kPa})$ & $(\mathrm{kPa})$ & & \\
\hline \multirow{8}{*}{$N P$} & \multirow{2}{*}{$25-30$} & $J$ & $1.51(0.01)$ & $17.4(0.2)$ & 2349 (637) & $126(12)$ & $-/-$ & $1 \mathrm{c}$ \\
\hline & & $J$ & $1.46(0.09)$ & $21.4(1.1)$ & $1010(360)$ & 83 (28) & $-/-$ & $\mathrm{n}$ \\
\hline & \multirow{2}{*}{$35-40$} & W & $1.55(0.04)$ & $19.5(0.3)$ & 1417 (486) & 98 (17) & - & $1 c$ \\
\hline & & $J$ & $1.56(0.06)$ & $22.0(1.3)$ & $1020(660)$ & 88 (36) & $+/-$ & $1 c$ \\
\hline & \multirow{2}{*}{$45-50$} & $W$ & $1.54(0.06)$ & $19.5(0.1)$ & 1274 (658) & 140 (13) & $-/-$ & $\mathrm{n}$ \\
\hline & & $J$ & $1.46(0.04)$ & $20.2(1.0)$ & $1720(280)$ & 154 (37) & $-/-$ & $\mathrm{n}$ \\
\hline & \multirow{2}{*}{$55-60$} & $W$ & $1.60(0.03)$ & $18.9(0.6)$ & 1440 (338) & 140 (19) & $+/-$ & 1c \\
\hline & & $J$ & $1.44(0.05)$ & $17.3(0.8)$ & $1240(470)$ & $206(21)$ & $-/-$ & $\mathrm{n}$ \\
\hline$O b$ & $25-30$ & $\bar{W}$ & $1.56(0.06)$ & $18.5(0.8)$ & 3650 (320) & $234(35)$ & $+/+$ & $3 c$ \\
\hline
\end{tabular}


Kinga Śnieg, Dariusz Błażejczak

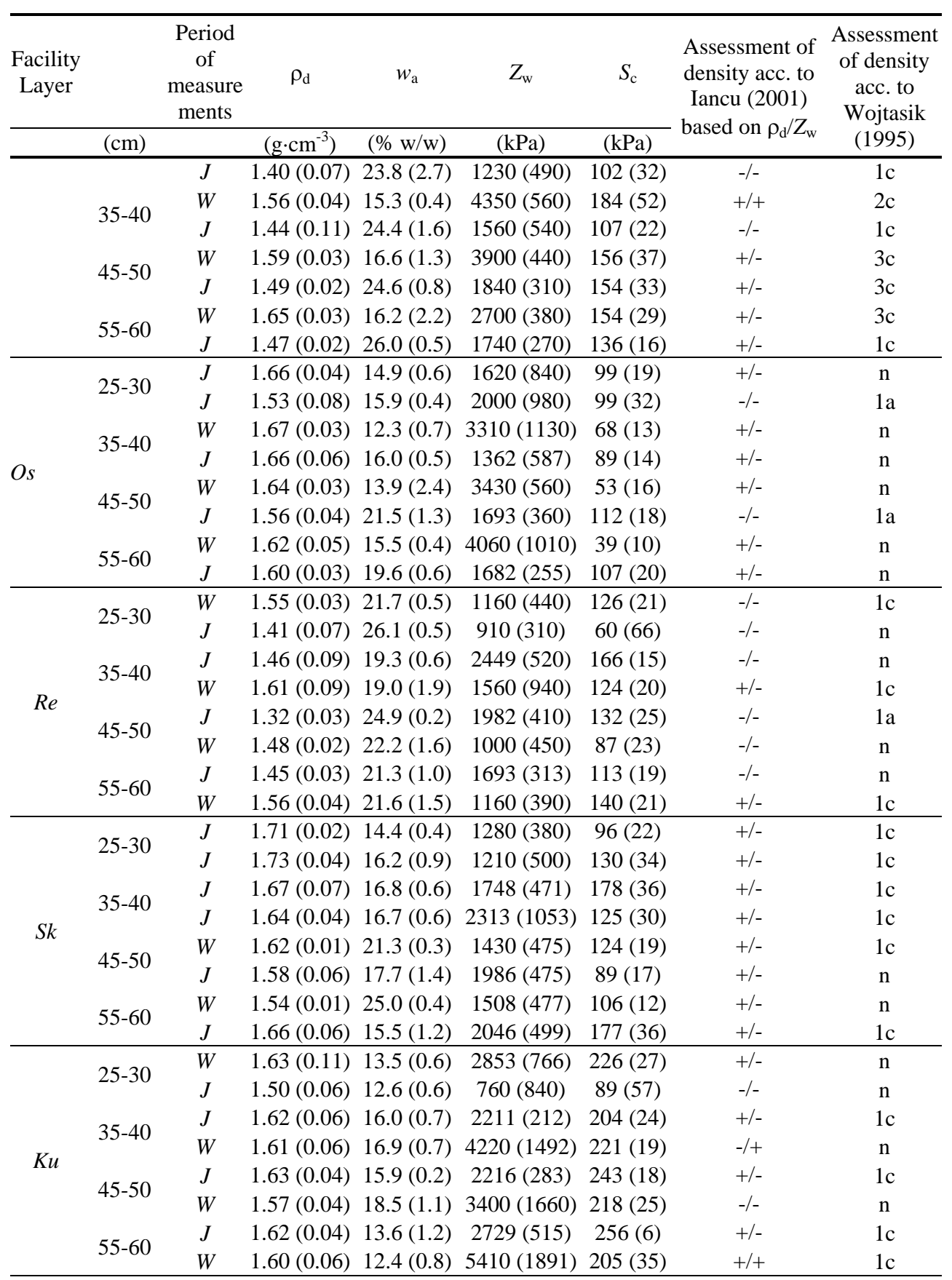

Notice: brackets include values of standard deviations; "+" or "-" exceeding or lack of exceeding of the critical value; $1 \mathrm{a}$ - slightly scarified soil, $\mathrm{n}$ - soil with natural density, $1 \mathrm{c}$ - slightly compacted soil, $2 \mathrm{c}$ - averagely compacted soil, 3c - strongly compacted soil 
Evaluation of subsoil...

Results of determination of the optimal moisture content $\left(w_{\mathrm{opt}}\right)$, ratio of present dry density of solid particles $\left(\rho_{\mathrm{d}}\right)$ and maximum density $\left(\rho_{\mathrm{ds}}\right)$ were presented in table 3 . Values $\rho_{\mathrm{d}} / \rho_{\mathrm{ds}}$ were within 0.74 to 0.98 and their median was equal to 0.87 . Those results were similar to the ones obtained by other authors for the arable layer (Carter, 1990). In the field conditions $\rho_{\mathrm{d}}$ in any of the investigated objects did not exceed the value of $\rho_{\mathrm{ds}}$. Therefore, it was confirmed that assuming in the discussion on the level of soil density that $\rho_{\mathrm{d}} \leq \rho_{\mathrm{ds}}$ should be recognized as justified. When comparing the value of the ratio with the results of assessment of soil density (Table 2) it was obtained that soil may be recognized as excessively compacted, meeting jointly requirements of Iancu's (2001) and Wojtasik (1995) procedures if the value of $\rho_{\mathrm{d}} / \rho_{\mathrm{ds}}$ exceeds 0.87 . On the other hand, soil is not excessively compacted when $\rho_{\mathrm{d}} / \rho_{\mathrm{ds}}$ does not exceed 0.77 . Values $\rho_{\mathrm{d}} / \rho_{\mathrm{ds}}$ between 0.77 and 0.87 allow, in relation to the granulometric composition of soils, recognition of its density degree as raised. Table 3 presents also results of calculations of the packing density value $\left(P_{\mathrm{d}}\right)$.

Table 3.

Values of optimal moisture content $\left(w_{\text {opt }}\right)$, ratio of dry density of solid particles and maximum density $\left(\rho_{d} / \rho_{d s}\right)$ soils, packing density $\left(P_{d}\right)$, difference of the volumetric density of solid particles and forecast volumetric density of solid particles of soil $\left(\rho_{d}-\rho_{d m}\right)$

\begin{tabular}{|c|c|c|c|c|c|c|}
\hline Facility & $\begin{array}{l}\text { Layer } \\
(\mathrm{cm})\end{array}$ & $\begin{array}{l}\text { Period of mea- } \\
\text { surements }\end{array}$ & $\begin{array}{c}w_{\mathrm{opt}} \\
(\% \mathrm{w} / \mathrm{w})\end{array}$ & $\begin{array}{c}\rho_{\mathrm{d}} / \rho_{\mathrm{ds}} \\
\left(\mathrm{g} \cdot \mathrm{cm}^{-3}\right)\end{array}$ & $\begin{array}{c}P_{\mathrm{d}} \\
\left(\mathrm{g} \cdot \mathrm{cm}^{-3}\right)\end{array}$ & $\begin{array}{r}\rho_{\mathrm{d}}-\rho_{\mathrm{dm}} \\
\left(\mathrm{g} \cdot \mathrm{cm}^{-3}\right)\end{array}$ \\
\hline \multirow{8}{*}{$N P$} & \multirow{2}{*}{$25-30$} & $J$ & 17.0 & 0.88 & 1.61 & -0.19 \\
\hline & & $J$ & 17.0 & 0.85 & 1.56 & -0.08 \\
\hline & \multirow{2}{*}{$35-40$} & $W$ & 15.7 & 0.89 & 1.65 & -0.06 \\
\hline & & $J$ & 15.7 & 0.90 & 1.66 & 0.00 \\
\hline & \multirow{2}{*}{$45-50$} & $W$ & 14.5 & 0.88 & 1.62 & -0.10 \\
\hline & & $J$ & 14.5 & 0.77 & 1.44 & -0.26 \\
\hline & \multirow{2}{*}{$55-60$} & $W$ & 13.2 & 0.89 & 1.74 & -0.07 \\
\hline & & $J$ & 13.2 & 0.80 & 1.58 & -0.29 \\
\hline \multirow{8}{*}{$O b$} & \multirow{2}{*}{$25-30$} & $W$ & 19.0 & 0.98 & 1.80 & -0.05 \\
\hline & & $J$ & 19.0 & 0.88 & 1.64 & $\mathrm{pz}$ \\
\hline & \multirow{2}{*}{$35-40$} & $W$ & 13.2 & 0.82 & 1.80 & -0.27 \\
\hline & & $J$ & 13.2 & 0.75 & 1.68 & -0.21 \\
\hline & \multirow{2}{*}{$45-50$} & $W$ & 11.5 & 0.82 & 1.82 & -0.28 \\
\hline & & $J$ & 11.5 & 0.77 & 1.72 & -0.12 \\
\hline & \multirow{2}{*}{$55-60$} & $W$ & 10.5 & 0.86 & 1.80 & -0.24 \\
\hline & & $J$ & 10.5 & 0.77 & 1.62 & $\mathrm{pz}$ \\
\hline \multirow{8}{*}{ Os } & \multirow{2}{*}{$25-30$} & $J$ & 11.7 & 0.86 & 1.74 & -0.18 \\
\hline & & $J$ & 11.7 & 0.79 & 1.61 & -0.29 \\
\hline & \multirow{2}{*}{$35-40$} & $W$ & 10.1 & 0.87 & 1.81 & -0.19 \\
\hline & & $J$ & 10.1 & 0.86 & 1.80 & -0.19 \\
\hline & \multirow{2}{*}{$45-50$} & $W$ & 11.7 & 0.85 & 1.83 & -0.19 \\
\hline & & $J$ & 11.7 & 0.81 & 1.75 & -0.12 \\
\hline & \multirow{2}{*}{$55-60$} & $W$ & 10.6 & 0.85 & 1.80 & -0.17 \\
\hline & & $J$ & 10.6 & 0.84 & 1.78 & -0.05 \\
\hline
\end{tabular}


Kinga Śnieg, Dariusz Błażejczak

\begin{tabular}{|c|c|c|c|c|c|c|}
\hline Facility & $\begin{array}{l}\text { Layer } \\
(\mathrm{cm})\end{array}$ & $\begin{array}{l}\text { Period of mea- } \\
\text { surements }\end{array}$ & $\begin{array}{c}w_{\mathrm{opt}} \\
(\% \mathrm{w} / \mathrm{w})\end{array}$ & $\begin{array}{c}\rho_{\mathrm{d}} / \rho_{\mathrm{ds}} \\
\left(\mathrm{g} \cdot \mathrm{cm}^{-3}\right)\end{array}$ & $\begin{array}{c}P_{\mathrm{d}} \\
\left(\mathrm{g} \cdot \mathrm{cm}^{-3}\right)\end{array}$ & $\begin{array}{l}\rho_{\mathrm{d}}-\rho_{\mathrm{dm}} \\
\left(\mathrm{g} \cdot \mathrm{cm}^{-3}\right)\end{array}$ \\
\hline \multirow{8}{*}{$R e$} & \multirow{2}{*}{$25-30$} & $W$ & 16.9 & 0.92 & 1.70 & -0.02 \\
\hline & & $J$ & 16.9 & 0.84 & 1.52 & $\mathrm{pz}$ \\
\hline & \multirow{2}{*}{$35-40$} & $J$ & 15.6 & 0.86 & 1.59 & -0.17 \\
\hline & & $W$ & 15.6 & 0.95 & 1.54 & -0.03 \\
\hline & \multirow{2}{*}{$45-50$} & $J$ & 15.2 & 0.75 & 1.43 & -0.12 \\
\hline & & $W$ & 15.2 & 0.85 & 1.59 & -0.05 \\
\hline & \multirow{2}{*}{$55-60$} & $J$ & 14.4 & 0.82 & 1.58 & 0.02 \\
\hline & & $W$ & 14.4 & 0.89 & 1.69 & 0.05 \\
\hline \multirow{8}{*}{$S k$} & \multirow{2}{*}{$25-30$} & $J$ & 13.0 & 0.96 & 1.91 & 0.00 \\
\hline & & $J$ & 13.0 & 0.97 & 1.93 & -0.05 \\
\hline & \multirow{2}{*}{$35-40$} & $J$ & 18.0 & 0.98 & 1.90 & -0.11 \\
\hline & & $J$ & 18.0 & 0.96 & 1.87 & -0.14 \\
\hline & \multirow{2}{*}{$45-50$} & $W$ & 15.9 & 0.91 & 1.88 & $\mathrm{pz}$ \\
\hline & & $J$ & 15.9 & 0.89 & 1.84 & -0.08 \\
\hline & \multirow{2}{*}{$55-60$} & $W$ & 16.8 & 0.86 & 1.72 & $\mathrm{pz}$ \\
\hline & & $J$ & 16.8 & 0.92 & 1.84 & -0.13 \\
\hline \multirow{8}{*}{$K u$} & \multirow{2}{*}{$25-30$} & $W$ & 11.2 & 0.83 & 1.73 & -0.29 \\
\hline & & $J$ & 11.2 & 0.74 & 1.55 & -0.33 \\
\hline & \multirow{2}{*}{$35-40$} & $J$ & 13.9 & 0.87 & 1.80 & -0.13 \\
\hline & & $W$ & 13.9 & 0.87 & 1.79 & 0.00 \\
\hline & \multirow[b]{2}{*}{$45-50$} & $J$ & 15.4 & 0.92 & 1.84 & -0.15 \\
\hline & & $W$ & 15.4 & 0.88 & 1.78 & -0.15 \\
\hline & \multirow{2}{*}{$55-60$} & $J$ & 16.8 & 0.93 & 1.84 & -0.04 \\
\hline & & $W$ & 16.8 & 0.92 & 1.82 & -0.01 \\
\hline
\end{tabular}

Notice: „pz" - means that it was impossible to determine $\rho_{\mathrm{dm}}$, because the scope of the model use was exceeded

Values $P_{\mathrm{d}}$, (Jones et al., 2003) allow assessment of susceptibility of subsoil to density. In 22 instances it was found out that the investigated soils are susceptible to compaction to

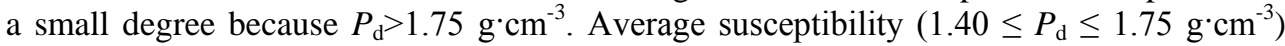
was obtained in 26 cases. Soils with high susceptibility to compaction were not reported $\left(P_{\mathrm{d}}<1.40\right)$. Comparing values of $P_{\mathrm{d}}$ with the results of Proctor's method of determination it may be proved (for $P_{\mathrm{d}}>1.75$ ), that soil is low susceptible to compaction if the average value $\rho_{d} / \rho_{d s}>0.89$. It may be also noticed that the values $\rho_{d} / \rho_{d s}$ increase with the growth of $P_{d}$. The research on the coefficient of correlation on $(r)$ between the values $\rho_{\mathrm{d}} / \rho_{\mathrm{ds}}$ a $P_{\mathrm{d}}$ proved that in general, the force of this relation was average $(r=0.56)$. However, the lowest statistically insignificant value $r$ was obtained for the object $O b(r=0.41)$ and the highest $K u$ $(r=0.97)$, namely respectively for soils with considerably the lowest and the highest content of sand fraction content. Table 3 also presents results of comparison of density $\rho_{\mathrm{d}}$ and $\rho_{\mathrm{dm}}$. It may be noticed that in the decisive majority of cases the value $\rho_{\mathrm{d}}$ was lower than $\rho_{\mathrm{dm}}$. Several instances $\rho_{\mathrm{dm}} \geq \rho_{\mathrm{d}}$ should be recognized as random and practically insignificant because the difference $\rho_{\mathrm{d}}-\rho_{\mathrm{dm}}$ was within $\pm 0.1 \mathrm{~g} \cdot \mathrm{cm}^{-3}$. It may prove that also at the moisture level of soil which differs from the optimal moisture content of its density in field conditions the value $\rho_{\mathrm{ds}}$ was not exceeded. 
Evaluation of subsoil...

\section{Conclusions}

1. The investigated soils in relation to the period and depth of measurement and their granulation group may be included to excessively compacted. But the lowest number of cases of excessive compaction was reported for soils with granulation of silt loam and loam with the content of particles $<0.002 \mathrm{~mm}$ which are within 9 to $15 \%$.

2. Soil may be considered as excessively compacted when the ratio of present dry density of solid particles $\left(\rho_{\mathrm{d}}\right)$ and the maximum density $\left(\rho_{\mathrm{ds}}\right)$, determined with Proctor's standard method, exceeds the value of 0.87 . Soil is not excessively densified when the ratio $\rho_{\mathrm{d}} / \rho_{\mathrm{ds}}$ does not exceed 0.77 . Values $\rho_{\mathrm{d}} / \rho_{\mathrm{ds}}$ between 0.77 and 0.87 allow, in relation to the granulometric composition of soils, recognize its density degree as raised.

3. The investigated soils, based on the analysis of the soil compaction values and its shear vane test and volumetric density of its mineral particles, may be included to susceptible to compaction in the average or small degree.

4. Present volumetric density of the solid particles of the investigated soils did not achieve the maximum values of volumetric densities, determined with the Proctor's method, which proves that these soils may be subjected to the process of further compaction.

5. Density of the investigated soils did not considerably exceed the values of volumetric densities read out from Proctor's curve for the moisture determined in the field conditions.

\section{References}

Aragón, A., García, M.G., Filgueira, R.R., Pachepsky, Ya.A. (2000). Maximum compactibility of Argentine soils from the Proctor test; The relationship with organic carbon and water content. Soil and Tillage Research, 56, 197-204.

Barzegar, A.R., Asoodar, M. A., Ansari, M. (2000). Effectiveness of sugarcane residue incorporation at different water contents and the Proctor compaction loads in reducing soil compactibility. Soil \& Tillage Research, 57, 167-172.

Błażejczak, D. (2010). Prognozowanie naprężenia granicznego $w$ warstwie podornej gleb ugniatanych kołami pojazdów rolniczych. Wyd. ZUT w Szczecinie. ISBN 978-83-7663-050-2.

Błażejczak, D., Dawidowski, J.B. (2013). Problem wykorzystania gęstości objętościowej gleby w ocenie jej zagęszczenia. Journal of Research and Applications in Agricultural Engineering, Vol. 58(1), 17-20.

Carter, M. R. (1990). Relative measures of soil bulk density to characterize compaction in tillage studies on fine sandy loams. Canadian Journal of Soil Science, 70, 425-433.

Dobrzański B. Zawadzki S. (red.), (1993): Gleboznawstwo. PWRiL, Warszawa, ISBN 83-09-00083-9.

Gregorich, E. G., Carter, M.R. (1997). Soil quality for crop production and ecosystem health. Developments in soil science 25. Elsevier, Amsterdam, ISBN 0-444-86661-5.

Hakansson, I., Lipiec, J. (2000). A revive of the usefulness of relative bulk density values in studies of soil structure and compaction. Soil and Tillage Research, 53, 71-85.

Iancu, M. (2001). Technique for Reducing Subsoil Compaction of Pedogenetic Origin. Proceedings of the 3rd INCO Copernicus Workshop on Subsoil Compaction, Busteni-Romania, June 14-18, 2001, 437-451.

Jones, R. J. A., Spoor, G., Thomasson A. J. (2003). Vulnerability of subsoil in Europe to compaction: a preliminary analysis. Soil \& Tillage Research, 73, 131-143.

Komornicki, T., Zasoński, S. (1965). Powtarzalność wyników oznaczeń niektórych właściwości fizycznych gleb. Roczniki Gleboznawcze, T. XV, z. 2. PWN Warszawa, 315-330. 
Krasowicz, S., Oleszek, W., Horabik, J., Dębicki, R., Jankowiak, J., Stuczyński, T., Jadczyszyn, J. (2011). Racjonalne gospodarowanie środowiskiem glebowym Polski. Polish Journal of Agronomy, 7, 43-58.

Kumar D., Bansal M. L., Phogat V. K. (2009). Compactability in relation to texture and organic matter content of alluvial soils. Indian Journal of Agricultural Research,43(3), 180-186.

PN-88/B-04481 (1988). Grunty budowlane. Badania próbek gruntu.

Soane, B.D., Blackwell, P.S., Dickson, J.W., Painter, D.J., (1980/1981). Compaction by agricultural vehicles: a review. I. Soil and wheel characteristics. Soil \& Tillage Research. 23, 207-237.

Szeptycki, A. (2003). Wpływ ciężkich maszyn rolniczych na fizykomechaniczne właściwości gleby. Journal of Research and Application in Agricultural Engineering, 48(2), 38-42.

Van den Akker, J. J. H., Arvidsson, J., Horn, R. (2003). Introduction to the special issue on experiences with the impact and prevention of subsoil compaction in the European Union. Soil \& Tillage Research, 73, 1-8.

Wagner, L. E., Ambe, N. M., Ding D. (1994). Estimating a Proctor Density Curve from Intrinsic Soil Properties. Transactions of the ASAE, 37(4), 1121-1125.

Wojtasik, M. (1995). Gęstość naturalna gleb mineralnych. WSP Bydgoszcz. ISBN 83-7096-076-6.

\section{OCENA ZAGESZCZENIA WARSTWY PODORNEJ GLEB PLASTYCZNYCH}

Streszczenie. Celem badań była ocena zagęszczenia gleby za pomocą wybranych wskaźników oraz wyznaczenie relacji pomiędzy nimi, ze szczególnym uwzględnieniem wyników uzyskanych metodą Proctora. Pomiary zwięzłości i oporów ścinania w ruchu obrotowym, gęstości objętościowej szkieletu gleby $\left(\rho_{\mathrm{d}}\right)$ oraz jej wilgotności wykonano w warstwach na głębokościach: 25-30, 35-40, 45-50 i 55-60 cm. Oznaczono także: maksymalną gęstość objętościową szkieletu metodą Proctora $\left(\rho_{\mathrm{ds}}\right)$, skład granulometryczny, zawartości węglanu wapnia i próchnicy, gęstość fazy stałej, odczyn oraz granice plastyczności i płynności. Obliczano także gęstość objętościową części mineralnych oraz gęstość naturalną. Stwierdzono, że zbadane gleby można ogólnie zaliczyć do nadmiernie zagęszczonych i podatnych na zagęszczanie w stopniu średnim lub małym. Wykazano, że glebę można uważać za nadmiernie zagęszczoną, gdy iloraz $\rho_{\mathrm{d}} / \rho_{\mathrm{ds}}$ przekracza wartość 0,87 .

Słowa kluczowe: gleba, zagęszczenie, ocena, gęstość objętościowa, metoda Proctora 